\title{
THERMAL HYDROLYSIS OF OLIVE LEAVES AND STEMS TO OBTAIN FERMENTABLE SUGARS
}

\author{
Fabiele Schaefer Rodrigues $^{1}$ (i), Norton Marozo Silveira ${ }^{1}$ (iD), Alexandre Gonçalves Kury ${ }^{1}$ (iD, Jefferson Fagundes da Silva ${ }^{1}$ (iD),
} Estêvão Santos Laureano da Cunha ${ }^{1}$ (iD), Marcus Vinícius Tres ${ }^{1}$ iD \& Giovani Leone Zabot ${ }^{1 *}$ (D)

1 - Federal University of Santa Maria, Laboratory of Agroindustrial Processes Engineering, Cachoeira do Sul, Rio Grande do Sul, Brazil

Keywords:
Biomass
Leaves
Subcritical water hydrolysis
Olive tree
Stems

\section{ABSTRACT}

Subcritical water hydrolysis was used for the pre-treatment of residues generated in olive groves. Fermentable sugars were produced from the lignocellulosic material found in olive leaves and stems. Firstly, moisture, ash, particle average diameter, and total extracts were measured. Afterward, subcritical water hydrolysis was carried out at $20 \mathrm{MPa}$ in a $50 \mathrm{~mL}$ reactor. The influences of two temperatures $\left(180\right.$ and $\left.220^{\circ} \mathrm{C}\right)$ and two water flow rates $\left(10\right.$ and $\left.20 \mathrm{~mL} \mathrm{~min}^{-1}\right)$ on the sugars yields were evaluated. The concentration of sugars was $31.3 \mathrm{~g} \mathrm{~L}^{-1}$ at $180^{\circ} \mathrm{C}$ and 10 $\mathrm{mL} \mathrm{\operatorname {min } ^ { - 1 }}$ in a reaction for $3 \mathrm{~min}$, of which glucose was the major sugar $\left(27.64 \mathrm{~g} \mathrm{~L}^{-1}\right)$. Statistical analysis was performed using Sisvar ${ }^{\circledR} 5.6$ software and the averages were compared through Tukey's test, considering a significance level of $95 \%(p<0.05)$. For the treatments evaluated in this work, only xylose was statistically different in the treatments with different water flow rates. The highest values of xylose were obtained with $10 \mathrm{~mL} \mathrm{~min}^{-1}$, which were $1.82 \mathrm{~g} \mathrm{~L}^{-1}$ (180 $\left.{ }^{\circ} \mathrm{C}\right)$ and $2.18 \mathrm{~g} \mathrm{~L}^{-1}\left(220^{\circ} \mathrm{C}\right)$. The total inhibitors were high at $220^{\circ} \mathrm{C}$ for all water flow rates, with a significant difference from the averages obtained at $180^{\circ} \mathrm{C}$.

\section{Palavras-chave:}

Biomassa

HIDRÓLISE TÉRMICA DE FOLHAS E TALOS DA COLHEITA DE AZEITONA

Folhas

Hidrólise subcrítica

Oliveiras

Talos PARA OBTENÇÃO DE AÇÚCARES FERMENTESCÍVEIS

\section{RESUMO}

Hidrólise com água subcrítica foi usada para o pré-tratamento de resíduos gerados em olivais. Assim, o objetivo deste trabalho foi aplicar a hidrólise com água subcrítica para obter açúcares fermentescíveis a partir de folhas e talos da colheita de azeitonas. A caracterização da biomassa consistiu na determinação de umidade, cinzas, diâmetro médio e extrativos totais. Após, foi realizada a hidrólise com água subcrítica a $20 \mathrm{MPa}$ em reator de $50 \mathrm{~mL}$, avaliando-se a temperatura $\left(180\right.$ e $\left.220^{\circ} \mathrm{C}\right)$ e a vazão de água $\left(10\right.$ e $\left.20 \mathrm{~mL} \mathrm{~min}^{-1}\right)$ sobre o rendimento de açúcares. A concentração dos açúcares redutores em 3 min de reação foi de $31,3 \mathrm{~g} \mathrm{~L}^{-1}$ na condição de temperatura de $180^{\circ} \mathrm{C}$ e vazão de $10 \mathrm{~mL} \mathrm{~min}^{-1}$. O maior rendimento de açúcares foi de glicose, resultando em $27,64 \mathrm{~g} \mathrm{~L}^{-1}$ na temperatura de $180^{\circ} \mathrm{C}$ e vazão de $10 \mathrm{~mL} \mathrm{~min}^{-1}$. Foi realizada análise estatística com o auxílio do software Sisvar ${ }^{\circledR} 5.6$, comparando-se as médias através do teste de Tukey, considerado nível de significância de $95 \%(\mathrm{p}<0,05)$. Dentre os açúcares da solução hidrolisada, somente a xilose apresentou diferença significativa entre as médias, no tempo de $3 \mathrm{~min}$. Os maiores valores de xilose foram obtidos em $10 \mathrm{~mL} \mathrm{~min}^{-1}$, sendo $1,82 \mathrm{~g} \mathrm{~L}^{-1}\left(180{ }^{\circ} \mathrm{C}\right)$ e $2,18 \mathrm{~g} \mathrm{~L}^{-1}\left(220^{\circ} \mathrm{C}\right)$. Os inibidores totais apresentaram os maiores resultados na temperatura de $220^{\circ} \mathrm{C}$, para ambas as vazões, havendo diferença significativa entre médias na temperatura de $180{ }^{\circ} \mathrm{C}$. 


\section{INTRODUCTION}

The olive tree (Olea europaea L.) is a dicotyledonous tree belonging to the Oleaceae botanical family from the Mediterranean region. The olive is a drupe-type fruit constituted by the cuticle, pulp, and core, and presents high commercial importance due to the production of olive oil (RAMALHEIRO, 2009). The tree has spindle-shaped, leathery and grayish-green leaves, with $5-6 \mathrm{~cm}$ long and $1-1.5 \mathrm{~cm}$ width in the middle of the leaf (KIPLE; ORNELAS, 2000; GRANADOS-PRINCIPAL et al., 2010).

Pruning is performed throughout the life of an olive tree to provide the maximum annual production (COUTINHO et al., 2009). After pruning and other treatments, the harvest is done, which generates a large amount of residues. According to Guilherme (2012), the residues from olive growing include olive pomace and leaves from the olive cleaning in mills, which are called biomass and can be valorized energetically. The beneficial properties of olive leaves encourage the development of new projects aiming at evaluating technological routes for future industrial exploration (GONÇALVES, 2009).

Overall, biomass is a renewable source of organic material and it is found in many segments, such as in agriculture, agro-industries, forests, and municipal wastewater, among others. The use of organic residues as a raw material for organic conversion by subcritical water hydrolysis is a promising strategy. According to Reddy (2014), water has a selective reaction capacity under subcritical conditions. Subcritical water presents the ability to break down the lignocellulosic complex into smaller molecules, such as fermentable sugars (PRADO et al., 2014). For the pre-treatment, the biomass should be mechanically broken or ground to increase the surface area (OGEDA; PETRI, 2010). However, the drying step is not mandatory if the material is immediately processed (BERGHETTI et al., 2020; SILVA et al., 2018). The characteristics of the agricultural residue used in subcritical water hydrolysis, such as cell wall structure, composition, type of connection, monosaccharides concentration, and lignin content, among others, determine the hydrolysis rates and yields (SILVA, 2019).

According to Abaide et al. (2019), the significant increase in energy and fuel demands coupled with a large amount of agricultural biomass produced worldwide provides an incentive to the development of research aimed at using lignocellulosic biomass as a source of bioproducts and renewable energy. Based on clean and sustainable technology, the hydrolysis with subcritical water is favorable for the dissociation of lignocellulosic biomass. Some studies have been conducted with subcritical water hydrolysis to convert agricultural residues, such as sugarcane bagasse (LACHOS-PEREZ et al., 2016), rice straw (CHEN et al., 2018), pecan residues (SANTOS et al., 2020), coconut husks (MUHARJA et al., 2020), and soybean straw and husks (VEDOVATTO et al., 2021). Therefore, this work aimed to apply subcritical water hydrolysis to obtain fermentable sugars from olive leaves and stems.

\section{Experimental}

Olive leaves and stems, which are residues from the harvest of Arbequina olives, were used as raw material. The biomass was obtained from Cachoeira do Sul, Brazil ( $30^{\circ} 0$ ' $45^{\prime}$ ' S, $52^{\circ} 55^{\prime}$ 11 " O) in the 2018-2019 harvest. The biomass was dried in a stove for $24 \mathrm{~h}$ at $60{ }^{\circ} \mathrm{C}$. Thereafter, a knife mill (SL-30, SOLAB, Brazil) was used to grind the samples to an average particle size of approximately $0.8 \mathrm{~mm}$ (Figure 1).

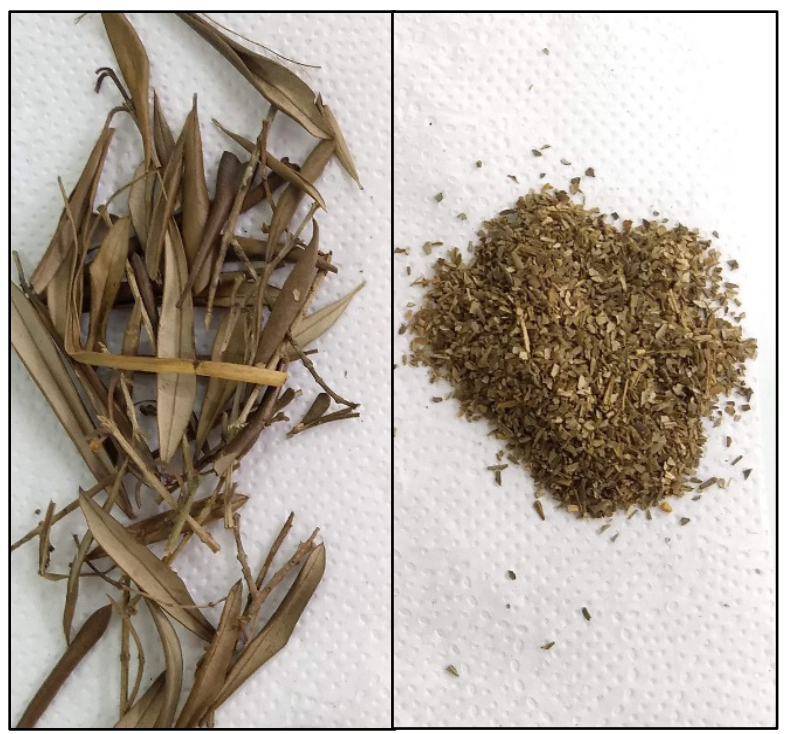

(A)

(B)

Figure 1. Olive leaves and stems: (a) before grinding and (b) after grinding

The steps regarding the characterization of biomass, pre-treatment, and analysis of hydrolysates are presented in Figure 2. 

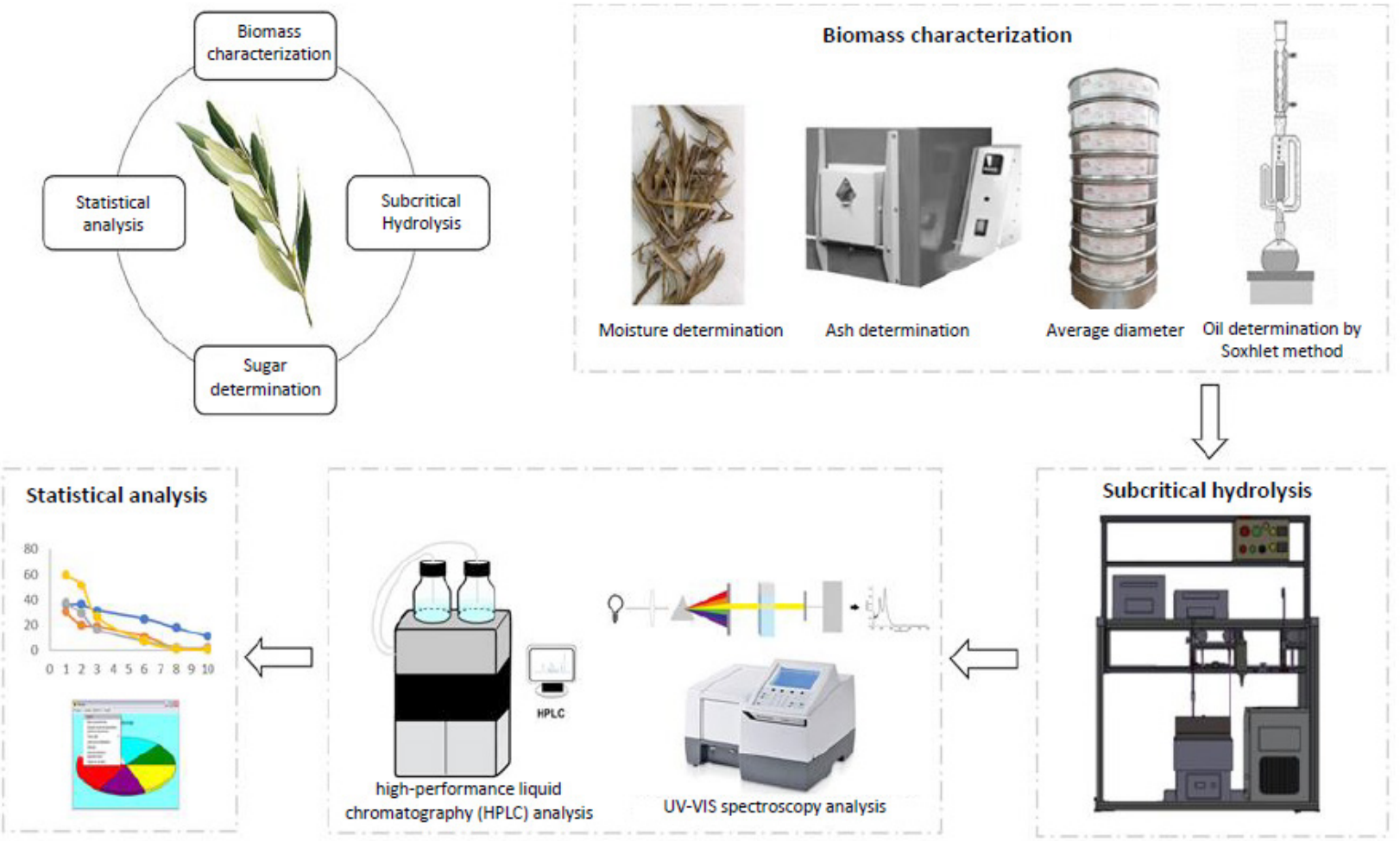

Figure 2. Scheme of the steps applied in the study

\section{Moisture determination}

For moisture determination, the mass of ground leaves and stems was measured before and after drying in a stove (SL-100, SOLAB, Brazil) at 105 ${ }^{\circ} \mathrm{C}$ for $24 \mathrm{~h}$. The results of moisture were presented as the average \pm standard deviation from the measurement with eight samples.

\section{Ash determination}

For ash determination, three samples containing $5 \mathrm{~g}$ of ground leaves and stems were placed in a muffle furnace and heated for $2 \mathrm{~h}$ according to the following heating ramps: $100{ }^{\circ} \mathrm{C} / 5 \mathrm{~min} ; 150^{\circ} \mathrm{C} /$ $10 \mathrm{~min} ; 200{ }^{\circ} \mathrm{C} / 10 \mathrm{~min} ; 250{ }^{\circ} \mathrm{C} / 10 \mathrm{~min} ; 300^{\circ} \mathrm{C}$ / $10 \mathrm{~min} ; 400{ }^{\circ} \mathrm{C} / 10 \mathrm{~min}$; and $550{ }^{\circ} \mathrm{C} / 2 \mathrm{~h}$. After incineration, the percent ash was calculated based on mass difference.

\section{Oil extraction}

Oil extraction from olive leaves and stems was performed by the Soxhlet method with n-hexane, following a methodology reported elsewhere (BRUM, 2004). N-hexane $(250 \mathrm{~mL})$ was added in a $500 \mathrm{~mL}$ volumetric flask and $5 \mathrm{~g}$ of ground biomass was wrapped with filter paper and placed in the extraction chamber (extractor). The extraction occurred continuously for $6 \mathrm{~h}$ with solvent reflux. Thereafter, the solvent was evaporated and separated from the solute (oil) using a rotary vacuum evaporator (SKL-25A, Even, Brazil).

\section{Average diameter}

The average diameter of the biomass was determined using sieves with pore diameters of $2.36 \mathrm{~mm}, 2.00 \mathrm{~mm}, 1.18 \mathrm{~mm}, 1.00 \mathrm{~mm}, 600 \mu \mathrm{m}$, $500 \mu \mathrm{m}, 300 \mu \mathrm{m}$, and $125 \mu \mathrm{m}$. The procedure consisted of initially placing $20 \mathrm{~g}$ of biomass on the sieve with the largest pore diameter. In the sequence, the sieves were agitated for $10 \mathrm{~min}$. The calculation of the average diameter was performed according to Equation 1.

$$
d_{m g}=\exp \left\{\frac{\sum_{i=1}^{n}\left[w_{i} \log \left(d_{i} \cdot d_{i+1}\right)^{0,5}\right]}{\sum_{i=1}^{n} w_{i}}\right\}
$$

where,

$\mathrm{d}_{\mathrm{mg}}$ - average diameter $(\mathrm{mm})$;

$d_{i}$ - nominal opening of the $i^{\text {th }}$ sieve $(\mathrm{mm})$;

$\mathrm{d}_{\mathrm{i}+1}$ - nominal opening of the $\mathrm{i}+1^{\text {th }}$ sieve $(\mathrm{mm})$;

$\mathrm{w}_{\mathrm{i}}$ - mass of the material retained on the $\mathrm{i}^{\text {th }}$ sieve (g). 


\section{Subcritical water hydrolysis}

After the biomass characterization, subcritical water hydrolysis was carried out to dissociate the lignocellulosic structure of the biomass into lower chain saccharides. The hydrolysis equipment used in this work is the same one reported by Abaide et al. (2019) and it is composed of a pre-heating bath, a high-pressure pump, a 316L stainless steel reactor with a volume of $50 \mathrm{~mL}$, anti-return valves, micrometering valve, piping, thermocouples, pressure gauges, and a temperature control system (Figure 3).

Subcritical water hydrolysis was carried out with $10 \mathrm{~g}$ of ground biomass. The outlet valve (number 10) was closed and the reactor was pressurized with preheated water at $80^{\circ} \mathrm{C}$. The pressure was set at $20 \mathrm{MPa}$ and the influences of temperature $\left(180\right.$ and $\left.220{ }^{\circ} \mathrm{C}\right)$ and water flow rates $(10$ and $20 \mathrm{~mL} / \mathrm{min}$ ) were evaluated. The hydrolysis was carried out for a total time of $10 \mathrm{~min}$ and, during this period, samples were collected in $1 \mathrm{~min}, 2$ $\mathrm{min}, 3 \mathrm{~min}, 6 \mathrm{~min}, 8 \mathrm{~min}$, and $10 \mathrm{~min}$. Based on the water flow rates, the final solvent to biomass ratios of $10 \mathrm{~g}$ water/g biomass and $20 \mathrm{~g}$ water/g biomass were reached. After performing the hydrolysis, the hydrolyzed samples were stored in a refrigerator in ambar flasks for further analysis. The experimental assays were performed in duplicate.

The determination of reducing sugars contained in the hydrolyzed samples was performed by the dinitrosalicylic acid (DNS) method using glucose as a standard solution (MILLER, 1959). The absorbance was measured by a spectrophotometer (UV-1900, Shimadzu, Japan) at a wavelength of $540 \mathrm{~nm}$ and compared to the standard curve prepared with glucose for the quantification of reducing sugars.

The hydrolyzed solutions were analyzed by high-performance liquid chromatography (HPLC) (Proeminence UFLC-Nexera XR, Shimadzu, Japan) using a refractive index (RI) detector (RID $10 \mathrm{~A}$, Shimadzu, Japan) to quantify xylose, glucose, cellobiose, and arabinose. The samples were filtered using a $0.22 \mu \mathrm{m}$ nylon membrane. An Asahipak $\mathrm{NH}_{2} \mathrm{P}-50$ amino column $(250 \mathrm{~mm} \times 4.6 \mathrm{~mm})$ (Asahi Kasei, Japan) was used at $50{ }^{\circ} \mathrm{C}$. The mobile phase

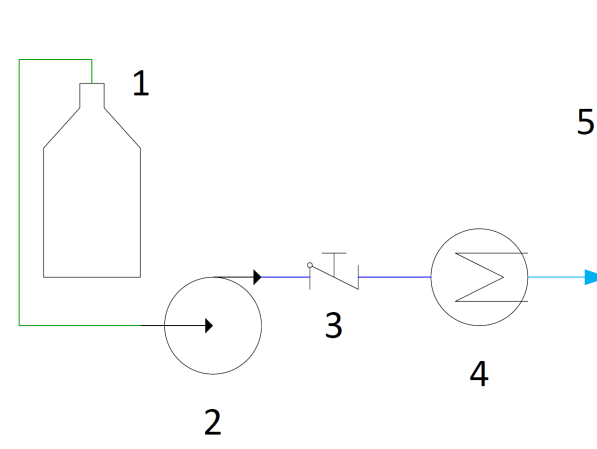

\begin{tabular}{|c|l|}
\hline $\mathbf{1}$ & Water reservoir \\
\hline $\mathbf{2}$ & Liquid pump \\
\hline $\mathbf{3}$ & Anti-return valve \\
\hline $\mathbf{4}$ & Pre-heating bath \\
\hline $\mathbf{5}$ & Safety valve \\
\hline $\mathbf{6}$ & Pressure gauge \\
\hline $\mathbf{7}$ & Reactor (with band heater) \\
\hline $\mathbf{8}$ & Temperature control system \\
\hline $\mathbf{9}$ & Cooling bath \\
\hline $\mathbf{1 0}$ & Blocking needle valve \\
\hline $\mathbf{1 1}$ & Micrometering valve \\
\hline $\mathbf{1 2}$ & Sample flask \\
\hline
\end{tabular}

\section{6}
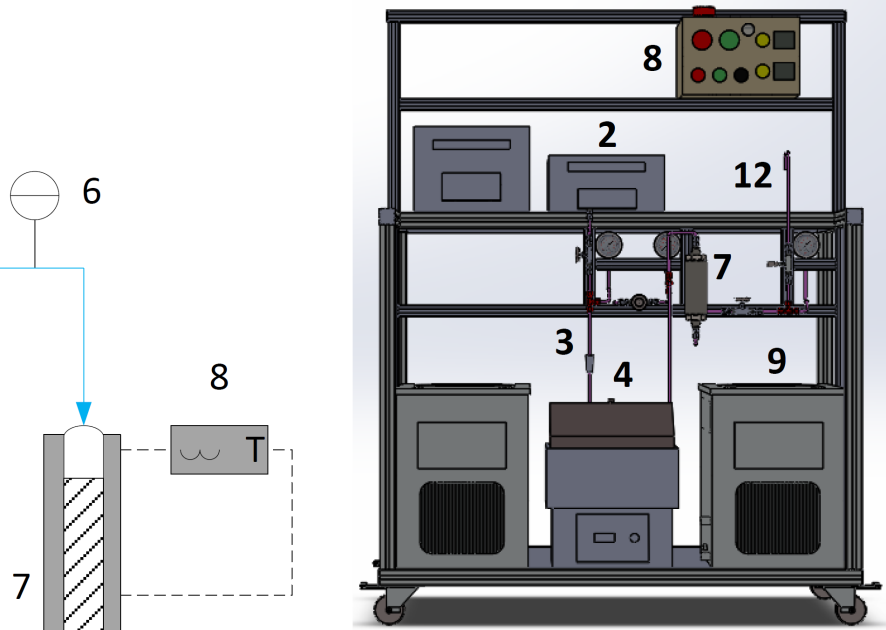

7

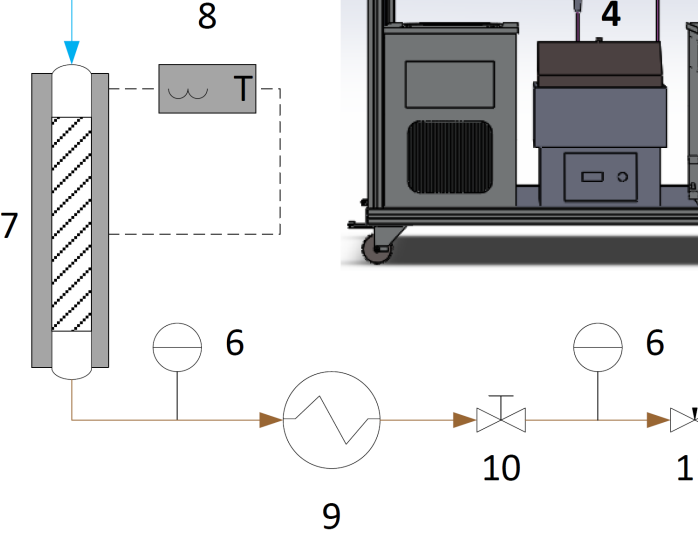

* The sizes are only illustrative

Source: ABAIDE et al. (2019), with copyright permission

Figure 3. Subcritical water hydrolysis equipment 
consisted of a solution of acetonitrile:water in the ratio 69:31. The flow rate of the mobile phase was $0.5 \mathrm{~mL} \mathrm{~min}^{-1}$ and the injection volume of each sample was $15 \mu \mathrm{L}$. The compounds were separated and analyzed at $30^{\circ} \mathrm{C}$ for a total time of $16 \mathrm{~min}$.

\section{Statistical analysis}

To evaluate the influence of each assay on the sugars yields, a statistical analysis was performed using the Sisvar ${ }^{\circledR} 5.6$ software. The Tukey's test was applied for the comparison of averages considering a significance level of $95 \%(p<0.05)$.

\section{RESULTS AND DISCUSSION}

The moisture content from the olive leaves and stems was $59.7 \pm 3.4 \%$. The ash determination indicated $3.38 \pm 0.02 \%$ (mass basis) and the average diameter was $0.84 \mathrm{~mm}$. The amount of oil obtained by the Soxhlet method was $1.72 \%$ (mass basis). Cagliari (2017) studied the influence of drying on olive leaves properties. Among the results found, olive leaves showed percentages of moisture and ash of $51.65 \%$ and $3.06 \%$, respectively. Similarly, Cavalheiro (2014) reported that the Arbequina cultivar grown in Caçapava do Sul (Brazil) showed moisture and ash contents of $58.68 \pm 0.07 \%$ and $4.38 \pm 0.18 \%$, respectively.

The assay $1\left(180{ }^{\circ} \mathrm{C} / \mathrm{V}-10\right)$ showed better results of sugar yield at $3 \mathrm{~min}$ and $10 \mathrm{~min}$ reaction times (Table 1). This result confirms the information regarding the efficiency of subcritical water hydrolysis in temperatures far from the critical point (ABAIDE et al., 2019). In assay $3\left(180{ }^{\circ} \mathrm{C} / \mathrm{V}-20\right)$, the sugar yield was low. This can be explained by the influence of the water flow rate because the residence time was not sufficient to complete the hydrolysis. Therefore, the lignocellulosic material was not completely dissociated. Unlike the behavior of assays 1 and 3 , assays $2\left(220^{\circ} \mathrm{C} / \mathrm{V}-10\right)$ and $4\left(220^{\circ} \mathrm{C} / \mathrm{V}-20\right)$ showed an inverse response when comparing the increase of water flow rate. In assay 4 , at a reaction time of $3 \mathrm{~min}$, where the flow rate was set at 20 $\mathrm{mL} / \mathrm{min}$, the yields were higher. Therefore, the influence of temperature was predominant and the flow rate was not a determining factor for obtaining the best hydrolysis results under these conditions.

The statistical comparison of reducing sugars was performed for each condition for $3 \mathrm{~min}$ and $10 \mathrm{~min}$. At $3 \mathrm{~min}$, none of the four assays showed a significant difference. At $10 \mathrm{~min}$, assay 1 showed a significant difference in the yield of reducing sugars when compared to the others. These results are in agreement with the findings reported by Santos et al. (2020), where an increase in the concentration of sugars was presented in the first reaction times and, in the sequence, a decrease in the values with increasing reaction time was reported.

The assays with a flow rate of $20 \mathrm{~mL} \mathrm{~min}{ }^{-1}$ (assays 3 and 4) show similarities in the behavior of sugars yields throughout the hydrolysis process, presenting high values in the first minutes of reaction and undergoing accelerated decay thereafter (Figure 4). Otherwise, the assays 1 and 2 , with a flow rate of $10 \mathrm{~mL} \mathrm{~min}{ }^{-1}$, did not present expressive yields at the beginning of the reaction. Also, a slower decay is seen. This behavior shows that the flow rate influences positively biomass hydrolysis because the assays with the flow rate of $20 \mathrm{~mL} \mathrm{~min}^{-1}$ have more available water to perform the conversion into smaller saccharides in shorter times.

Table 1. Yields of reducing sugars in hydrolyzed samples of olive leaves and stems for $3 \mathrm{~min}$ and $10 \mathrm{~min}$ of reaction times

\begin{tabular}{cccccc}
\hline \multirow{2}{*}{ Assay } & Code & $\begin{array}{c}\text { Flow rate } \\
\left(\mathrm{mL} \mathrm{min}^{-1}\right)\end{array}$ & Temperature $\left({ }^{\circ} \mathrm{C}\right)$ & \multicolumn{2}{c}{ Reducing sugars $\left(\mathrm{g} \mathrm{L}^{-1}\right)$} \\
\cline { 5 - 6 } & & & & $3 \mathrm{~min}$ & $10 \mathrm{~min}$ \\
\hline 1 & $180^{\circ} \mathrm{C} / \mathrm{V}-10$ & 10 & 180 & $31.3 \pm 5.6 \mathrm{a}$ & $11.0 \pm 2.4 \mathrm{~b}$ \\
2 & $220^{\circ} \mathrm{C} / \mathrm{V}-10$ & 10 & 220 & $18.8 \pm 3.1 \mathrm{a}$ & $1.9 \pm 0.3 \mathrm{a}$ \\
3 & $180^{\circ} \mathrm{C} / \mathrm{V}-20$ & 20 & 180 & $16.4 \pm 2.3 \mathrm{a}$ & $1.4 \pm 0.7 \mathrm{a}$ \\
4 & $220^{\circ} \mathrm{C} / \mathrm{V}-20$ & 20 & 220 & $26.4 \pm 2.1 \mathrm{a}$ & $0.7 \pm 0.1 \mathrm{a}$ \\
\hline
\end{tabular}

$\mathrm{V}$ : Volumetric flow rate; different letters in a column mean a significant difference in Tukey’s test at a significance level of $95 \%$ ( $\mathrm{p}<0.05$ ) 


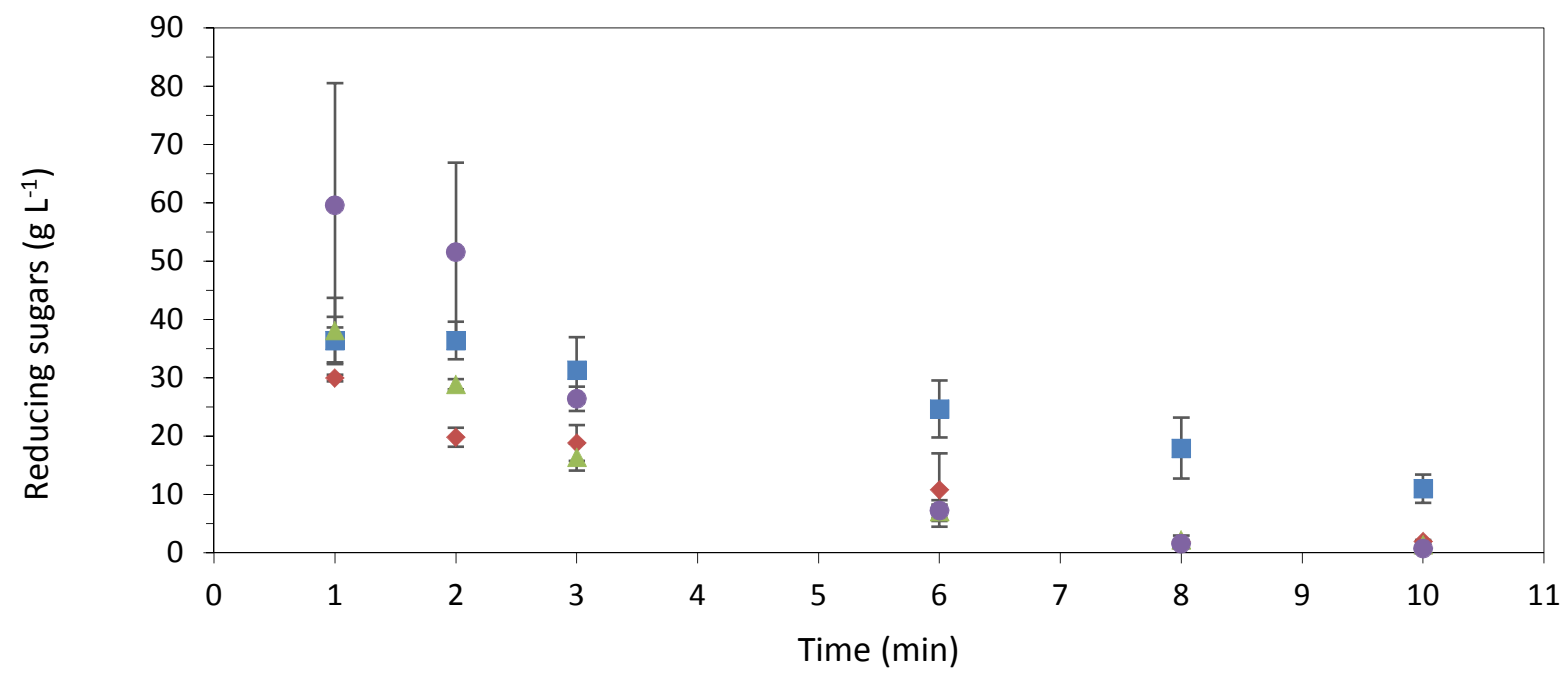

$\begin{array}{cccc}\text { Assay } 1 & \text { Assay } 2 & \text { Assay 3 } & \text { Assay } 4 \\ \square 180^{\circ} \mathrm{C} / \mathrm{V}-10 & 220^{\circ} \mathrm{C} / \mathrm{V}-10 & \Delta 180^{\circ} \mathrm{C} / \mathrm{V}-20 & 220^{\circ} \mathrm{C} / \mathrm{V}-20\end{array}$

Figure 4. Kinetic curves of reducing sugars obtained by subcritical water hydrolysis of olive leaves and stems

Cellulose and hemicellulose are dissociated into reducing sugars at higher rates in the first few minutes (Figure 4). The action of water as a dissociation solvent becomes less effective from the middle of the reaction onward (5-10 $\min$ ) because part of the cellulose and most of the hemicellulose fraction was dissociated at the beginning of the reaction (0-5 $\mathrm{min})$. If this graph is presented with cumulative mass values of sugars over time ( $\mathrm{g} / 100 \mathrm{~g}$ biomass), the curve could reach a constant plateau, especially after $8 \mathrm{~min}$ for the $180{ }^{\circ} \mathrm{C} / \mathrm{V}-20$ and $220{ }^{\circ} \mathrm{C}-\mathrm{V}-20$ conditions. This behavior is also reported with subcritical water hydrolysis of residual biomass from agricultural harvesting and processing (ABAIDE et al., 2019; SANTOS et al., 2020; VEDOVATTO et al., 2021).

Specific sugars found in the hydrolyzed solutions are presented in Table 2. Glucose is the sugar that presented the highest concentration in all assays. The highest glucose concentration is related to the assay performed with a flow rate of $10 \mathrm{~mL} \mathrm{~min}{ }^{-1}$. The sugars concentrations in the reaction time equal to $3 \mathrm{~min}$ are higher than the reaction time of $10 \mathrm{~min}$. Also, statistical analysis was performed for all sugars (xylose, arabinose, glucose, and cellobiose). At 3 min reaction time, only xylose showed a significant difference in the averages, while no differences were seen at $10 \mathrm{~min}$.
The order of sugars concentrations was glucose, arabinose, xylose, and cellobiose, corroborating the results obtained with other agricultural biomass, such as rice husk and pecan shell (ABAIDE et al., 2019; SANTOS et al., 2020).

The formation of inhibitors occurs throughout the hydrolysis process. The pentoses resulting from the hydrolysis of hemicellulose are degraded to furfural, while the inhibitor 5-hydroxymethylfurfural (HMF) results from the degradation of hexoses (JÖNSSON; MARTÍN, 2016). The decrease in the concentration of fermentable sugars coincides with the formation of furfural and HMF. Therefore, the fermentation yield to biofuel production decreases when these inhibitors start to accumulate (PALMQVIST; HAHN-HÄGERDAL, 2000).

Table 3 shows the concentrations of inhibitors after subcritical water hydrolysis of olive leaves and stems. Both HMF and furfural present the highest concentrations in assay 2 , at a flow rate of $10 \mathrm{~mL}$ $\min ^{-1}$ and temperature of $220^{\circ} \mathrm{C}$. The second-highest concentrations of these inhibitors are also found at $220{ }^{\circ} \mathrm{C}$, in assay 4 , where the flow rate is $20 \mathrm{~mL}$ $\min ^{-1}$. The assays at $180{ }^{\circ} \mathrm{C}$ (assay 1 and 3 ) showed higher values of HMF than furfural, while the assays 2 and $4\left(\right.$ at $220^{\circ} \mathrm{C}$ ) resulted in higher concentrations of furfural if compared to HMF. 
Table 2. Sugar yields of hydrolyzed solutions of olive leaves and stems at $3 \mathrm{~min}$ and $10 \mathrm{~min}$

\begin{tabular}{|c|c|c|c|c|}
\hline Assay & $1-180^{\circ} \mathrm{C} / \mathrm{V}-10$ & $2-220^{\circ} \mathrm{C} / \mathrm{V}-10$ & $3-180^{\circ} \mathrm{C} / \mathrm{V}-20$ & $4-220^{\circ} \mathrm{C} / \mathrm{V}-20$ \\
\hline \multicolumn{5}{|c|}{3 min reaction } \\
\hline \multicolumn{5}{|l|}{ Sugars $\left(\mathrm{g} \mathrm{L}^{-1}\right)$} \\
\hline Xylose & $1.82 \mathrm{~b}$ & $2.18 \mathrm{~b}$ & $0.46 \mathrm{a}$ & $0.54 \mathrm{a}$ \\
\hline Arabinose & $3.32 \mathrm{a}$ & $3.27 \mathrm{a}$ & $1.53 \mathrm{a}$ & $1.65 \mathrm{a}$ \\
\hline Glucose & $27.64 \mathrm{a}$ & $16.09 \mathrm{a}$ & $10.80 \mathrm{a}$ & $7.52 \mathrm{a}$ \\
\hline Cellobiose & $0.85 \mathrm{a}$ & $1.83 \mathrm{a}$ & $0.13 \mathrm{a}$ & $0.19 \mathrm{a}$ \\
\hline TOTAL & 33.63 & 23.37 & 12.92 & 9.90 \\
\hline \multicolumn{5}{|c|}{10 min reaction } \\
\hline \multicolumn{5}{|l|}{ Sugars $\left(\mathrm{g} \mathrm{L}^{-1}\right)$} \\
\hline Xylose & $0.19 \mathrm{a}$ & $0.03 \mathrm{a}$ & $0.84 \mathrm{a}$ & $0.00 \mathrm{a}$ \\
\hline Arabinose & $1.01 \mathrm{a}$ & $0.32 \mathrm{a}$ & $2.67 \mathrm{a}$ & $0.09 \mathrm{a}$ \\
\hline Glucose & $6.52 \mathrm{a}$ & $1.63 \mathrm{a}$ & $8.39 \mathrm{a}$ & $0.11 \mathrm{a}$ \\
\hline Cellobiose & $0.26 \mathrm{a}$ & $0.04 \mathrm{a}$ & $0.45 \mathrm{a}$ & $0.02 \mathrm{a}$ \\
\hline TOTAL & 7.98 & 2.02 & 12.35 & 0.22 \\
\hline
\end{tabular}

V: Volumetric flow rate; different letters in a row mean a significant difference in Tukey's test at a significance level of $95 \%(\mathrm{p}<0.05)$

Table 3. Quantification of inhibitors in hydrolyzed solutions from olive leaves and stems.

\begin{tabular}{ccccccccc}
\hline & & \multicolumn{7}{c}{ Inhibitors $\left(\mathrm{g} \mathrm{L}^{-1}\right)$} \\
\cline { 3 - 9 } Assay & Code & \multicolumn{7}{c}{ HMF $\left(\mathrm{g} \mathrm{L}^{-1}\right)$} \\
\cline { 3 - 9 } & & $1 \mathrm{~min}$ & $2 \mathrm{~min}$ & $3 \mathrm{~min}$ & $6 \mathrm{~min}$ & $8 \mathrm{~min}$ & $10 \mathrm{~min}$ & Total \\
\hline 1 & $180^{\circ} \mathrm{C} / \mathrm{V}-10$ & 0.017 & 0.025 & 0.022 & 0.059 & 0.031 & 0.029 & 0.183 \\
2 & $220^{\circ} \mathrm{C} / \mathrm{V}-10$ & 0.187 & 0.193 & 0.200 & 0.198 & 0.165 & 0.072 & 1.015 \\
3 & $180^{\circ} \mathrm{C} / \mathrm{V}-20$ & 0.027 & 0.041 & 0.036 & 0.011 & 0.003 & 0.002 & 0.120 \\
4 & $220^{\circ} \mathrm{C} / \mathrm{V}-20$ & 0.199 & 0.166 & 0.198 & 0.085 & 0.008 & 0.004 & 0.660 \\
\hline & & & & & Furfural $\left(\mathrm{g} \mathrm{L} \mathrm{L}^{-1}\right)$ & & & \\
\hline Assay & $\mathrm{Code}$ & $1 \mathrm{~min}$ & $2 \mathrm{~min}$ & $3 \mathrm{~min}$ & $6 \mathrm{~min}$ & $8 \mathrm{~min}$ & $10 \mathrm{~min}$ & Total \\
\hline 1 & $180^{\circ} \mathrm{C} / \mathrm{V}-10$ & 0.002 & 0.004 & 0.006 & 0.013 & 0.014 & 0.008 & 0.047 \\
2 & $220^{\circ} \mathrm{C} / \mathrm{V}-10$ & 0.208 & 0.259 & 0.273 & 0.235 & 0.192 & 0.069 & 1.236 \\
3 & $180^{\circ} \mathrm{C} / \mathrm{V}-20$ & 0.004 & 0.009 & 0.011 & 0.000 & 0.001 & 0.001 & 0.026 \\
4 & $220^{\circ} \mathrm{C} / \mathrm{V}-20$ & 0.250 & 0.200 & 0.226 & 0.075 & 0.006 & 0.001 & 0.758 \\
\hline
\end{tabular}

In the reaction time of $3 \mathrm{~min}$, all sugars showed higher concentrations at the flow rate of $10 \mathrm{~mL} / \mathrm{min}$. The increase in temperature from $180^{\circ} \mathrm{C}$ to $220^{\circ} \mathrm{C}$ did not influence the concentration. In the reaction time of $10 \mathrm{~min}$, the highest sugars concentrations were found at the lowest temperature studied (180 ${ }^{\circ} \mathrm{C}$ ). This behavior correlates with the formation of inhibitors because they are more concentrated at higher temperatures. The results and behavior are in agreement with the findings reported by Jönsson and Martin (2016).

Total concentrations of inhibitors quantified throughout the hydrolysis process are presented in Table 4. Assays with lower flow rates exhibited higher concentrations of inhibitors. The statistical analysis showed a significant difference in assays 2 and 4 if compared to the other assays. The highest concentration of inhibitors presented at $220{ }^{\circ} \mathrm{C}$ agrees with the results obtained by Abaide et al. (2019), Santos et al. (2020), and Vedovatto et al. (2021). The authors reported that the temperature increment in the hydrolysis process increases the concentration of inhibitors due to the dissociation of cellulose. 
RODRIGUES, F. S. et al.

Table 4. Quantification of total inhibitor during the hydrolysis reaction

\begin{tabular}{ccccc}
\hline Inhibitors & $\begin{array}{c}\text { Assay } 1 \\
180^{\circ} \mathrm{C} / \mathrm{V}-10\end{array}$ & $\begin{array}{c}\text { Assay } 2 \\
220^{\circ} \mathrm{C} / \mathrm{V}-10\end{array}$ & $\begin{array}{c}\text { Assay 3 } \\
180^{\circ} \mathrm{C} / \mathrm{V}-20\end{array}$ & $\begin{array}{c}\text { Assay 4 } \\
220^{\circ} \mathrm{C} / \mathrm{V}-20\end{array}$ \\
\hline HMF & 0.183 & 1.015 & 0.120 & 0.660 \\
Furfural & 0.047 & 1.236 & 0.026 & 0.758 \\
\hline TOTAL & $0.230 \mathrm{a}$ & $2.251 \mathrm{~b}$ & $0.146 \mathrm{a}$ & $1.418 \mathrm{~b}$ \\
\hline
\end{tabular}

Different letters in a row mean a significant difference in Tukey's test at a significance level of $95 \%(\mathrm{p}<0.05)$

\section{CONCLUSIONS}

Fermentable sugars were more concentrated in the hydrolysates collected at the beginning of the reaction time in subcritical water hydrolysis in a semi-continuous mode. Reaction temperatures far from the critical point, such as $180{ }^{\circ} \mathrm{C}$, are also efficient in obtaining smaller sugars when low flow rates are used. When the hydrolysis process involves higher temperatures, the water flow rate does not influence the yields. The highest concentrations of inhibitors occurred in the assays with the highest reaction temperature.

\section{AUTHORSHIP CONTRIBUTION STATEMENT}

RODRIGUES, F.S.: Conceptualization, Formal Analysis, Investigation, Methodology, Writing original draft; SILVEIRA, N.M.: Investigation, Methodology, Writing - review \& editing; KURY, A.G.: Investigation, Methodology; SILVA, J.F.: Investigation, Methodology; CUNHA, E.S.L.: Data curation, Investigation, Methodology, Validation; TRES, M.V.: Data curation, Formal Analysis, Resources, Software, Writing - original draft; ZABOT, G.L.: Conceptualization, Funding acquisition, Project administration, Supervision, Writing - review \& editing.

\section{DECLARATION OF INTERESTS}

The authors declare that they have no known competing financial interests or personal relationships that could have appeared to influence the work reported in this paper.

\section{ACKNOWLEDGMENTS}

The authors thank the Coordenação de
Aperfeiçoamento de Pessoal de Nível Superior (CAPES), Conselho Nacional de Desenvolvimento Científico e Tecnológico (CNPq) and Fundação de Amparo à Pesquisa do Estado do Rio Grande do Sul (FAPERGS) for financial support, graduate scholarships and research productivity grants.

\section{REFERENCES}

ABAIDE, E. R.; MORTARI, S. R.; UGALDE, G.; VALÉRIO, A.; AMORIM, S. M.; DI LUCCIO, M.; MOREIRA, R. de F. P. M.; KUHN, R. C.; PRIAMO, W. L.; TRES, M. V.; ZABOT, G. L.; MAZUTTI, M. A. Subcritical water hydrolysis of rice straw in a semi-continuous mode. Journal of Cleaner Production, v.209, p.386-397, 2019.

BERGHETTI, J.; PADILHA, M. S.; BORBA, P. T. D. de.; COELHO, C. M. M. Physiological changes in wheat seeds during the artificial drying process. Revista Engenharia na Agricultura, Viçosa, v.28, p.336-342, 2020.

BRUM, A. A. S. Métodos de extração e qualidade da fração lipídica. $66 \mathrm{f}$. Dissertação de Mestrado, Escola Superior de Agricultura Luiz de Queiroz, Piracicaba, 2004.

CAGLIARI, A. Influência da secagem convectiva em leito fixo sobre as propriedades da folha de oliveira (Olea europaea L.). 100f. Dissertação de Mestrado, Universidade Federal do Pampa, Bagé, 2017.

CAVALHEIRO, C. V.; ROSSO, V. D.; PAULUS, E.; CICHOSKI, A. J.; WAGNER, R.; MENEZES, C. R.; BARIN, J. S. Composição química de folhas de oliveira (Olea europaea L.) da região de Caçapava do Sul, RS. Ciência Rural, Santa Maria, v.44, n.10, p.1874-1879, 2014. 
CHEN, J.; ZHANG, C.; LI, M.; CHEN, J.; WANG, Y.; ZHOU, F. Microwave-enhanced sub-critical hydrolysis of rice straw to produce reducing sugar catalyzed by ionic liquid. J Mater Cycles Waste Manag, v.20, p.1364-1370, 2018.

COUTINHO, E. F.; RIBEIRO, F. C.; CAPPELLARO, T. H. Cultivo de Oliveira (Olea europaea L.). Pelotas: Embrapa Clima Temperado, 2009.

GONÇALVES, R. A. C. Incorporação de folha de oliveira na dieta de suínos em crescimento: efeito nas performances, digestibilidade, parâmetros sanguíneos e características da carne. $53 \mathrm{f}$. Dissertação de Mestrado, Universidade de Trás-osMontes e Alto Douro, Vila Real, 2009.

\section{GUILHERME, V. DA R. S. Biodegradação} Anaeróbia do Bagaço de Azeitona. 2012. 130 f. Dissertação de Mestrado, Universidade da Beira Interior, Covilhã, 2012.

GRANADOS-PRINCIPAL, S.; QUILES. J. L.; RAMIREZ-TORTOSA, C. L.; SANCHEZROVIRA, P.; RAMIREZ-TORTOSA, M. C. Hydroxytyrosol: from laboratory investigations to future clinical trials. Nutrition Reviews, v.68, n.4, p.191-206, 2010.

JÖNSSON, L. J.; MARTÍN, C. Pretreatment of lignocellulose: Formation of inhibitory byproducts and strategies for minimizing their effects. Bioresource Technology, v.199, p.103-112, 2016.

KIPLE, K. F.; ORNELAS K. C. The Cambridge World History of Food. New York: Cambridge University Press, 2000.

LACHOS-PEREZ, D.; MARTINEZ-JIMENEZ, F.; REZENDE, C. A.; TOMPSETT, G.; TIMKO, M.; FORSTER-CARNEIRO, T. Subcritical water hydrolysis of sugarcane bagasse: An approach on solid residues characterization. The Journal of Supercritical Fluids, v.108, p.69-78, 2016.
MILLER, G. L.; Use of Dinitrosalicylic Acid Reagent for Determination of Reducing Sugar. Analytical Chemistry, v.31, n.3, p.426-428, 1959.

MUHARJA,M.;FADHILAH,N.;DARMAYANTI, R. F.; SANGIAN, H. F.; NURTONO, T.; WIDJAJA, A. Effect of Severity Factor on the Subcritical Water and Enzymatic Hydrolysis of Coconut Husk for Reducing Sugar Production. Bulletin of Chemical Reaction Engineering \& Catalysis, v.15, n.3, p.786-797, 2020.

OGEDA, T. L.; PETRI, D. F. S. Hidrólise Enzimática de Biomassa. Quím. Nova, São Paulo, v.33, n.7, p.1549-1558, 2010.

PALMQVIST, E.; HAHN-HÄGERDAL, B. Fermentation of lignocellulosic hydrolysates. II: inhibitors and mechanisms of inhibition. Bioresource Technology, v.74, p.25-33, 2000.

PRADO, J. M.; FORSTER-CARNEIRO, T.; ROSTAGNO, M. A.; FOLLEGATTI-ROMERO, L. A.; MAUGERI FILHO, F.; MEIRELES, M. A. A. Obtaining sugars from coconut husk, defatted grape seed, and pressed palm fiber by hydrolysis with subcritical water. The Journal of Supercritical Fluids, v.89, p.89-98, 2014.

RAMAlHeIRO, J. P. DA S. C. Contribuição para a caracterização bioquímica do estado de maturação de azeitonas de diferentes variedades. 51 f. Dissertação de Mestrado, Universidade Técnica de Lisboa, Lisboa, 2009.

REDDY, H. K.; MUPPANENI, T.; SUN, Y.; LI, Y.; PONNUSAMY, S.; PATIL, P. D.; DAILEY, P.; SCHAUB, T.; HOLGUIN, F. O.; DUNGAN, B.; COOKE, P.; LAMMERS, P.; VOORHIES, W.; LU, X.; DENG, S. Subcritical water extraction of lipids from wet algae for biodiesel production. Fuel, v.133, p.73-81, 2014.

SANTOS, M. S. N.; ZABOT, G. L.; MAZUTTI, M. A.; UGALDE, G. A.; REZZADORI, K.; TRES, M. V. Optimization of subcritical water hydrolysis of pecan wastes biomasses in a semi-continuous mode. Bioresource Technology, v.306, p.123-129, 2020. 
RODRIGUES, F. S. et al.

SILVA, F. W. M. Valorização da biomassa residual da indústria de açaí (Euterpe oleracea Martius) através da integração entre as tecnologias hidrotérmica e digestão anaeróbia. 88f. Dissertação de Mestrado, Universidade Estadual de Campinas, Campinas, 2019.

SILVA, F. P.; SIQUEIRA, V. C.; QUEQUETO, W. D.; JUNQUEIRA, M. H.; GONELI, A. L. D. Propriedades físicas dos grãos de niger. Revista
Engenharia na Agricultura, Viçosa, v.26, n.6, p.507-515, 2018.

VEDOVATTO, F.; UGALDE, G.; BONATTO, C.; BAZOTI, S. F.; TREICHEL, H.; MAZUTTI, M. A.; ZABOT, G. L.; TRES, M. V. Subcritical water hydrolysis of soybean residues for obtaining fermentable sugars. The Journal of Supercritical Fluids, v.167, p. 1-12, 2021. 